\title{
ZAGROŻENIA BEZPIECZEŃSTWA ZDROWOTNEGO ZWIĄZANE Z TECHNOLOGIAMI INFORMATYCZNO-KOMUNIKACYJNYMI
}

\author{
Liliana Węgrzyn-Odzioba \\ Wydział Politologii, Uniwersytet Marii Curie-Skłodowskiej w Lublinie \\ ORCID: 0000-0002-3897-8843 \\ e-mail: liliana.wegrzyn-odzioba@poczta.umcs.lublin.pl
}

\begin{abstract}
Streszczenie: $W$ artykule podjęta została próba uchwycenia podstawowych elementów związanych z zagrożeniami zdrowotnymi dla bezpieczeństwa społecznego. Zwrócono uwagę na różne kategorie krzyżujących się tematów obejmujących zagrożenia natury zdrowotnej związane z zagrożeniami o charakterze psychicznym, fizycznym i moralnym. Tematyka ta jest trudnym badawczo obszarem, ponieważ szybkość i pogłębiająca się penetracja przez rzeczywistość wirtualną powoduje nakładanie się różnych elementów na siebie. Zagrożenia bezpieczeństwa zdrowotnego związane z rozwojem TIK to wyzwanie dla autorów zajmujących się tą problematyką, jak również praktyków różnych dziedzin, przed którymi stoi wyzwanie przewidzenia i prewencji potencjalnie niebezpiecznych zjawisk.
\end{abstract}

Słowa kluczowe: TIK, Internet, bezpieczeństwo zdrowotne, zagrożenia fizyczne, cyberprzestrzeń, zagrożenia psychiczne, technologia informacyjna

\section{WPROWADZENIE}

Ochrona zdrowia to priorytetowa dziedzina z zakresu bezpieczeństwa społecznego. Zaawansowany rozwój technologii informacyjno-kumunikacyjnych wspiera rozwój systemów organizacji opieki medycznej, jednocześnie wspomagając rozwój nowoczesnych metod diagnozowania i leczenia. Często w literaturze podejmowana jest problematyka zagrożeń, jakie dla pojedynczego człowieka niesie nadużywanie technologii informacyjnych. W niniejszym artykule na podstawie analizy literatury, dokumentów i danych statystycznych zostanie podjęta próba uchwycenia podstawowych elementów związanych z wpływem i zagrożeniami, jakie technologie informacyjno-komunikacyjne stwarzają dla zdrowia. Mając świadomość niezwykle złożonego charakteru badanego obszaru, autorka przy- 
jęła jako problem badawczy stwierdzenie, że technologie informacyjno-komunikacyjne, pod pojęciem których rozumie się „zaangażowanie w pozyskiwanie, gromadzenie, przetwarzanie i dystrybuowanie informacji przez sprzęty elektroniczne, takie jak komputer, telefon, radio czy telewizja" [Collin, Głowiński 1999], mogą generować różnorakie zagrożenia dla zdrowia ludzi. Zarówno literatura, jak i badania dotyczące tego tematu mają charakter rozproszony, ponieważ badacze reprezentujący często odległe od siebie dyscypliny podejmują analizy akcentujące specyficzne, osadzone w konkretniej dyscyplinie problemy. Niemniej jednak opis zagrożeń dla zdrowia podejmowany przez informatyków, psychologów, psychiatrów, fizjoterapeutów, pedagogów, neurologów, socjologów i innych bardzo często pozwala odnaleźć powiązania przyczynowo-skutkowe między nimi, zachęcając do interdyscyplinarnego ujęcia zagadnienia. Jednocześnie zakres tematyczny jest w ciągłym rozwoju, z jednej strony w związku z możliwościami diagnostycznymi, które zwracają uwagę na pomijane lub niezauważalne we wcześniejszych fazach problemy, z drugiej zaś ze względu na ciągły i dynamiczny rozwój technologii informacyjno-komunikacyjnych ${ }^{1}$. Wśród autorów podejmujących tę problematykę należy wymienić Kimberly Young, Patrice Klausing, Patricię Wallace, Jamie Bartletta, Janice M. Morse, Peggy Anne Field, Matthew W. Kreutera, Irene Joos, Susan Flores, Stanisława Kozaka, Łukasza Wojtasika, Jarosława Grotha, Mirosława Marodego, Bartłomieja Szmajdzińskiego, Małgorzatę Przybysz-Zarębę, Andrzeja Augustynka, Katarzynę Kliszewską, Dominika Batorskiego, Manfreda Spitzera czy Claya Shirky’ego. Istnieje również znaczący zbiór czasopism, które zajmują się tą problematyką $\mathrm{w}$ ramach poszczególnych dyscyplin lub interdyscyplinarnie $^{2}$. Bardzo wyraźnie widać również, że tematyka ta w literaturze anglo-

1 W tekście zamiennie stosowane są sformułowania „technologie informacyjne”/,technologie informacyjno-komunikacyjne".

2 K. Young, P. Klausing OSF, Uwolnić się z sieci. Uzależnienie od Internetu, Katowice 2009; J.M. Morse, A.P. Field, Qualitative research methods for health professionals, London 1995; Tailoring Health Messages. CustomizingCommunication With Computer Technology, ed. M.W. Kreuter, D. W. Farrell, L. R. Olevitch, L. K. Brennan, Routledge 1999; I. Joos, Introduction to Computers For Healthcare Professionals, 2005, wyd. 1; B. Szmajdziński, Syndrom uzależnienia od Internetu, Warszawa 2007; S. Flores, Sfejsowani. Jak media społecznościowe wplywaja na nasze życie, emocje i relacje z innymi, Warszawa 2017; M. Przybysz-Zaręba, Uzależnienie młodzieży od wspótczesnych mediów, Olsztyn 2008; S. Kozak, Patologie komunikowania w Internecie, Warszawa 2011; Patologie w cyberświecie, red. S. Bębas, J. Plis, J. Bednarek, Radom 2012; Ł. Wojtasik, Przemoc rówieśnicza z użyciem mediów elektronicznych - wprowadzenie do problematyki, „Dziecko Krzywdzone” 2009, nr 1 (26); J. Groth, Cyberstalking - perspektywa psychologiczna, „Forum Oświatowe” 2010, $\mathrm{nr} 2$ (43); A. Andrzejewska, (Nie)bezpieczny komputer: od euforii do uzależnień, Warszawa 2008; Cyberświat-możliwości i zagrożenia, red. J. Bednarek, A. Andrzejewska, Warszawa 2009; S. Juszczyk, Człowiek ws świecie elektronicznych mediów - szanse i zagrożenia (o problemach tworzacego się społeczeństwa informacyjnego), Katowice 2000; M. Castells, Galaktyka Internetu: refleksje nad Internetem, biznesem i spoleczeństwem, tłum. T. Hornowski, Poznań 2003; Internet: między edukacja, bezpieczeństwem a zdrowiem, red. M. Kowalski, Tychy 2008; P. Aftab, Internet a dzieci: uzależnienia i inne niebezpieczeństwa, Warszawa 2003; W.J. Paluchowski, Internet a psychologia: możliwości i zagrożenia, Warszawa 2009; S. Bębas, Patologie społeczne w sieci, Toruń 2013; P. Wal- 
języcznej była eksplorowana od lat 90 . XX wieku, pojawiając się w literaturze polskojęzycznej znacznie później.

W artykule uwaga zostanie skupiona na zagrożeniach, niemniej jednak istnieje wiele powiązań między technologią informacyjną a szeroko rozumianą problematyką ochrony zdrowia, w których, jak już wspomniano, nowoczesne technologie są nieocenionym wsparciem. Oprócz tego prace z ostatnich lat wprowadziły tak zaawansowane rozwiązania, które dostrzegają zagrożenia generowane przez technologie informacyjne i pomagają między innymi lekarzom i świadomym użytkownikom w walce z nimi. Przykładem są tutaj aplikacje i programy komputerowe, które monitorują aktywność użytkowników i inicjują przerwy w pracy lub rozrywce (RSI-Shield, BreakReminder, Ergonomix for Windows/ MacBreakZ, Ergotimer, RSIGuard, WorkPace RSI Software, Stretchy, Big Stretch Reminder, WorkRave, Awareness, Stand Up i in.) lub diagnozują niektóre problemy, jak chociażby aplikacja Nałogometr opracowana merytorycznie przez Instytut Psychologii Polskiej Akademii Nauk, który przeprowadził (2018/2019) Ogólnopolskie Badanie Nałogów.

\section{POJĘCIE TECHNOLOGII INFORMACYJNEJ I JEJ CHARAKTERYSTYKA}

Pojęcie information technology po raz pierwszy pojawiło się w artykule $\mathrm{Ma}$ nagement in the 1980s Harolda J. Leavitta i Thomasa L. Whislera opublikowanym w 1958 roku przez „Harvard Business Review” [Encyklopedia zarzadzania 2018]. Jak już wspomniano, szeroko pojęte IT to zespół środków (komputery czy sieci komputerowe), narzędzi (software-oprogramowania), jak również i technologii (np. telekomunikacja). Tym samym obejmuje więc swoim zakresem zarówno informatykę, jak i komunikację [Encyklopedia zarządzania 2018]. Dynamiczny

\footnotetext{
lace, Psychologia Internetu, Poznań 2001; A. Augustynek, Uzależnienia komputerowe: diagnoza, rozpowszechnienie, terapia, Warszawa 2010; P. Majchrzak, N. Ogińska-Bulik, Uzależnienie od internetu, Łódź 2010; P. Chocholska, M. Osipczuk, Uzależnienie od komputera i Internetu u dzieci i młodzieży, Warszawa 2009; N.A. Christakis, J.H. Fowler, W sieci, Sopot 2011; E. Aboujaoude, Wirtualna osobowość naszych czasów: mroczna strona e-osobowości, Kraków2012; D. Batorski, Uwarunkowania i konsekwencje korzystania z technologii informacyjno-komunikacyjnych, [w:] Diagnoza społeczna 2007. Warunki i jakość życia Polaków, red. J. Czapiński, T. Panek, Warszawa 2007, s. 268-288; M. Spitzer, Cyberchoroby. Jak cyfrowe życie rujnuje nasze zdrowie, Słupsk 2016; W. Furmanek, Zagrożenia wynikajace z rozwoju technologii informacyjnych, „Dydaktyka Informatyki" 2014, nr 9, s. 20-48, czy publikacje popularnonaukowe: J. Bartlett, The Dark Net, 2014; L. Penny, Cybersexism, 2013; P.J. Carnes, D.L. Demonico, E. Griffin, J.M. Moriarty, In the Shadows of the Net: Breaking free of Compulsive Online Sexual Behaviour, 2009; E. Lucas, Cyberphobia: Identity, Trust, Security and the Internet, 2015; C. Shirky, Here Comes Everybody: The Power of Organizing Without Organizations, 2008; N. Carr, The Shallows: what the Internet is doing to our brains, 2010; K.S. Young Pathological Internet use: A case that breaks the stereotype. Psychological Reports, 1996; K. S. Young, Caught in the Net, 1998; „International Journal of Computers in Healthcare”; „Journal of Telemedicine and Telecare”; „International Journal of Telemedicine and Applications”; „Technology and Health Care”; „Studies in Health Technology and Informatics”.
} 
rozwój technologii informatycznych oraz relatywny spadek cen narzędzi i usług związanych z technologiami spowodował, że w państwach wysoko rozwiniętych zmniejszyła się liczba osób wykluczonych z „kultury informatycznej” [Chen, Wellman 2004] $]^{3}$. Niemniej jednak zwłaszcza w państwach rozwijających się liczba osób bez dostępu do nowoczesnych technologii ciągle jest znacząca. Zarówno badania „We are social” ze stycznia 2018, jak i analizy Eurostatu z tego okresu wyraźnie wskazują, że i w ramach Unii Europejskiej występują znaczące różnice. Wśród obywateli Danii, Luksemburga, Szwecji, Niderlandów, Zjednoczonego Królestwa, Finlandii, Holandii i Niemiec odsetek osób korzystających z internetu kształtował się na poziomie ponad $90 \%$, a jednocześnie w państwach, takich jak Rumunia i Bułgaria, z internetu korzystało odpowiednio 64\% i 63\% mieszkańców. W 2017 roku odsetek mieszkańców UE-28, którzy nigdy nie korzystali z internetu, wyniósł 13\% [Internet access of house holds 2017]. Jan van Dijk w pracy Spoteczne aspekty nowych mediów [2010] stwierdził, że w wyniku podziału cyfrowego powstały trzy warstwy społeczne: elita informacyjna, uczestnicząca większość, niepodłączeni i wykluczeni ${ }^{4}$.

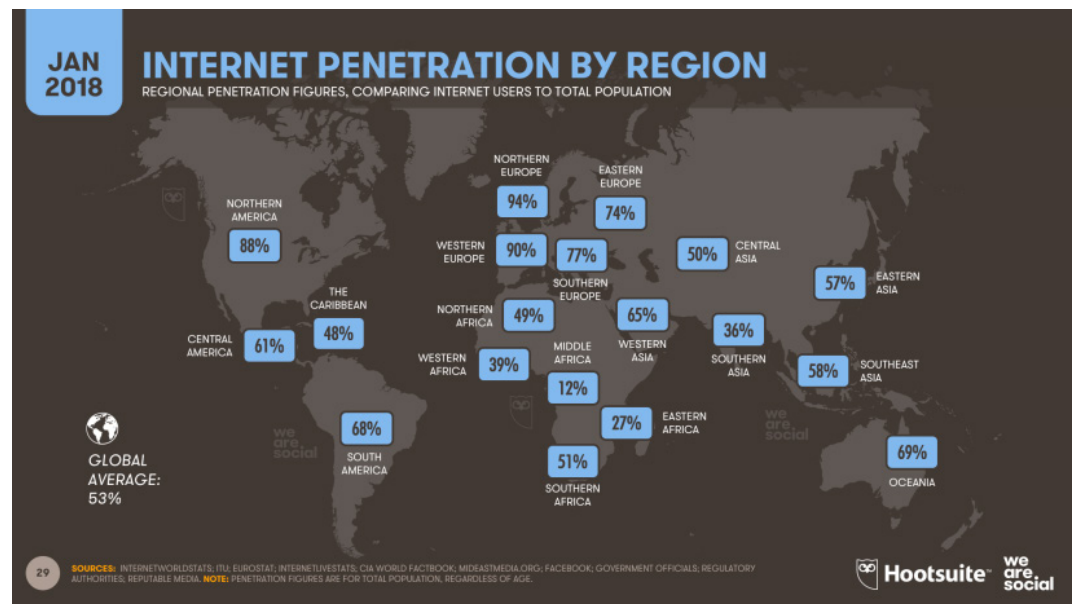

Mapa 1. Poziom dostępu do internetu na świecie.

Źródło: We are social, https://wearesocial.com/blog/2018/01/global-digital-report-2018 [dostęp: 12.02.2019].

Liczba użytkowników internetu według danych z 30 czerwca 2018 roku opublikowanych przez World Internet Users osiągnęła liczbę 4208439277 osób [Internet usagestatistics 2018]. W Polsce według danych grupy Polskie Badania Internetu liczba internautów w marcu 2018 roku wynosiła ogółem nieco po-

3 Na kulturę informatyczną składa się posiadanie urządzeń umożliwiających aktywne użytkowanie sieci, szerokopasmowa infrastruktura, znajomość języka angielskiego, umiejętności techniczne oraz sprawność poznawcza związana z „cyfrowym zanurzeniem” [Wąsiński 2003].

4 Wykluczenie cyfrowe rozumiane jest jako brak umiejętności lub umiejętności ograniczone w posługiwaniu się technologiami informatycznymi [DiMaggio, Hargittai 2001; Foulger 2001; Chen, Wellman 2004]. 
nad 28 milionów, z czego użytkowników komputerów osobistych i laptopów 24,5 miliona, a urządzeń mobilnych (smartfony i tablety) - 22,2 miliona [Polski Internet w marcu 2018]. Dane OECD dotyczące wykluczenia cyfrowego wskazały w grupie wiekowej 16-24 udział 97\%, zaś w grupie wiekowej 55-74 do 63\% użytkowników [OECD Digital Economy Outlook 2017]. Tym samym stopień nasycenia rynku należy uznać za wysoki.

Przełom XX i XXI wieku to dynamiczny rozwój technologii informatycznych, który poszerzył krąg odbiorców o tych uczestników, dla których internet to nie tylko praca, lecz przede wszystkim rozrywka. Firma „We are social” opublikowała raport z danymi na koniec marca 2018 roku, wskazując w swoich infografikach na udział w rynku mediów społecznościowych 3297000 użytkowników i 5061000 użytkowników telefonów komórkowych [Q2 Global Digital Statshot 2018].

Tabela 1. Użytkownicy internetu na świecie. Statystyka populacji, 30 czerwca 2018

\begin{tabular}{|c|r|r|r|r|r|}
\hline Regiony & $\begin{array}{c}\text { Ludność } \\
\text { (2018 Est.) }\end{array}$ & $\begin{array}{c}\text { Procentowy } \\
\text { udział } \\
\text { ludności }\end{array}$ & $\begin{array}{c}\text { Użytkownicy } \\
\text { internetu } \\
31.12 .2017\end{array}$ & $\begin{array}{c}\text { Wzrost } \\
2000-2018\end{array}$ & $\begin{array}{c}\text { Użytkownicy } \\
\text { internetu (\%) }\end{array}$ \\
\hline Afryka & 1287914329 & $16,9 \%$ & 46923169 & $10,199 \%$ & $11,0 \%$ \\
\hline Azja & 4207588157 & $55,1 \%$ & 2062197366 & $1,704 \%$ & $49,0 \%$ \\
\hline Europa & 827650849 & $10,8 \%$ & 705064923 & $570 \%$ & $16,8 \%$ \\
\hline $\begin{array}{c}\text { Ameryka Środkowa } \\
\text { i Karaiby }\end{array}$ & 652047996 & $8,5 \%$ & 438248446 & $2,325 \%$ & $10,4 \%$ \\
\hline Bliski Wschód & 254438981 & $3,3 \%$ & 164037259 & $4,894 \%$ & $3,9 \%$ \\
\hline Ameryka Północna & 363844662 & $4,8 \%$ & 345660847 & $219 \%$ & $8,2 \%$ \\
\hline Oceania/Australia & 41273454 & $0,6 \%$ & 28439277 & $273 \%$ & $0,7 \%$ \\
\hline Świat & 7634758428 & $100,0 \%$ & 4208439277 & $1,066 \%$ & $100,0 \%$ \\
\hline
\end{tabular}

Źródło: World Internet Usage and Populations Statistic, https://www.internetworldstats.com/stats.htm [dostęp: 3.01.2019].

Interesujące są również dane dotyczące wieku użytkowników internetu, ponieważ wskazują one jednoznacznie na osoby poniżej 50. roku życia jako te, które najczęściej korzystają z zaawansowanych rozwiązań technologicznych. Tym samym w kontekście tematu tej pracy to właśnie te grupy wiekowe powinny być szczególnie monitorowane jako narażone na różnego typu zagrożenia. Natomiast brakuje na tyle dłuższej perspektywy, która pozwalałaby przeanalizować, co dalej z osobami, które są obecnie poddawane oddziaływaniu technologii informatycznych i związanych z nimi niekorzystnych zjawisk. Czy osoby należące do pokolenia $\mathrm{Z}$ i Y ${ }^{5}$, czy inaczej pokolenia screenteenagersów (tzw. pokolenie ekranowe), które stanowią prawie 2/3 wszystkich użytkowników serwisu Facebook w Polsce, z upływem czasu będą nadal najaktywniejszymi użytkownikami mediów spo-

5 Pokolenie (generacja) Y, czyli millenialsi, za których uważa się osoby urodzone pomiędzy 1984 a 1996 rokiem, oraz pokolenie (generacja) Z - osoby urodzone według niektórych badaczy po 1997 roku, według innych po roku 2000. 
łecznościowych i ogólnie technologii informatycznych, czy z upływem czasu ich aktywność będzie się zmniejszała? [Raport Newspoint].

Raport Newspoint „Pokolenia w Polsce i potrzeba monitorowania ich rosnącej aktywności” wskazuje, że w najaktywniejszych na Facebooku grupach wiekowych dane z Polski i ze świata są porównywalne i wynoszą w grupie wiekowej 25-34 lata po 29\%, interesująca jest natomiast różnica w dwóch pierwszych grupach wiekowych, w których osiągnięto odpowiednio wyniki dla grupy 13-17 lat: Polska 13\%, świat 8\% i dla grupy 18-24: świat 29\%, Polska 23\%. W Polsce w świetle badań przeprowadzonych w 2013 roku zanotowano również, że aż 83\% dziesięciolatków posiadało telefony komórkowe [Yapp 2012] ${ }^{6}$. Natomiast w badaniach Teresy Borowskiej [2009], która posłużyła się modelem Kimberly Young, objawy uzależnienia od internetu wykazano u około 15\% polskich nastolatków.

\section{RODZAJE ZAGROŻEŃ ZDROWOTNYCH ZWIĄZANYCH Z TECHNOLOGIĄ INFORMACYJNĄ?}

Wprowadzając problematykę potencjalnych zagrożeń związanych z technologiami informacyjnymi i komunikacyjnymi, należy zwrócić uwagę na szczególne powiązanie tego zagadnienia ze sferą świadomości danego podmiotu (człowieka, grupy społecznej, narodu) i obiektywnego lub subiektywnego odbioru zjawisk, które mogą być oceniane jako niekorzystne lub niebezpieczne [Dworecki 2002]. W związku z tym należy je analizować w kategoriach poczucia bezpieczeństwa oraz odzwierciedlenia w świadomości realnego lub potencjalnego zagrożenia. Oznacza to tym samym, że może być niezgodna ze stanem faktycznym, ponieważ uwzględnia nie tylko obiektywne, ale przede wszystkim subiektywne aspekty zagrożeń i bezpieczeństwa [Zięba 1999] ${ }^{8}$. Posługując się modelem szwajcarskiego politologa Daniela Frei, należy oprzeć badania na analizie następujących komponentów:

1) stan braku bezpieczeństwa (rzeczywiste zagrożenie, adekwatnie postrzegane);

2) stan obsesji (nieznaczne zagrożenie, ale postrzegane nieadekwatnie jako duże);

3) stan fałszywego bezpieczeństwa (zagrożenie poważne, ale nieadekwatnie postrzegane jako niewielkie);

4) stan bezpieczeństwa (zagrożenie nieznaczne, adekwatnie postrzegane) [Frei 1977].

6 Średnia międzynarodowa w tym badaniu wynosiła $45 \%$. Wyniki w pozostałych państwach: Wielka Brytania - 73\%, Brazylia - 73\%, Niemcy - 69\%, Meksyk - 68\%, Chiny - 49\%, Hiszpania $-37 \%$, USA - 31\%, Australia - 31\%, Japonia - 20\%, Kanada - 17\%, Francja - 10\% [Yapp 2012].

7 W paragrafie tym znajdują się odniesienia do artykułu: [Węgrzyn-Odzioba 2018].

8 Por. [Witaszek 2013: 194-195], na temat badania zagrożeń: [Loranty 2012: 10-18]. 
Istnieje wiele typologii zagrożeń związanych z korzystaniem z technologii informacyjnych i w związku z tym zagrożenia związane z nimi w odniesieniu do zdrowia mogą być analizowane jako:

1) zagrożenia zdrowia fizycznego;

2) zagrożenia zdrowia psychicznego, a w jego ramach:

- zagrożenia związane z uzależnieniami,

- zagrożenia dla strefy mentalności.

W katalogu Waldemara Furmanka [Furmanek 2014] zagrożenia dla zdrowia to:

1) zagrożenia o charakterze psychologicznym:

- wewnętrzny przymus bycia w sieci,

- ucieczka od świata realnego do sztucznego świata wirtualnego,

- dostęp do patologicznych grup kulturowych,

- alienacja (np. alienuje telepraca);

2) zagrożenia o charakterze medycznym:

- zagrożenia zdrowia człowieka powodowane m.in. pracą przy komputerze czy szkodliwością promieniowania monitora komputera.

Należy jednak zgodzić się z twierdzeniem, że wiele z tych zagrożeń ma charakter krzyżowy i powiązania między nimi stanowią dodatkowy element komplikujący zarówno w obszarze badania tematu, jak i prewencji wobec zagrożeń.

Na hybrydowy charakter zagrożeń związanych z technologiami cyfrowymi w odniesieniu do zdrowia w sposób niezwykle szeroki zwrócił uwagę Mariusz Jędrzejko w pracy Cyfrowi tubylcy [2013]. Walka z zagrożeniami hybrydowymi w ramach zagrożeń dla zdrowia wymaga zmiany sposobu patrzenia na bezpieczeństwo jako takie. Przede wszystkim obok działań państw w pierwszej kolejności prawnych i edukacyjnych powinny zostać wzmocnione treści mające na celu rozwijanie świadomości ludzi w kwestii bezpieczeństwa w kategoriach jednostkowych.

\section{ZAGROŻENIA DLA ZDROWIA PSYCHICZNEGO}

Zagrożenia zdrowia psychicznego i fizycznego stanowią jeden z najbardziej czytelnych zagrożeń związanych z technologiami. Zarówno w odniesieniu do jednostki, jak i społeczeństwa zwraca uwagę fakt silnego skorelowania wielu patologii społecznych $\mathrm{z}$ ich osadzeniem $\mathrm{w}$ internecie.

Znacznie poważniejsze od skutków fizycznych uzależnienia od technologii informacyjnych są skutki psychologiczne, których konsekwencją mogą być problemy w komunikacji werbalnej i niewerbalnej, na co już obecnie zwracają uwagę badacze analizujący zachowania osób zaliczanych do pokolenia Z. Wśród najczęstszych negatywnych skutków psychologicznych „cybernałogów” można wymienić: zaburzenia pamięci i koncentracji, zaniedbywanie życia rodzinnego, problemy w nawiązywaniu i utrzymywaniu relacji interpersonalnych, fobie społeczne (które mogą prowadzić nawet do skrajnego wyalienowania), stany 
depresyjne, porzucenie dotychczasowych zainteresowań, zaniedbywanie podstawowych obowiązków szkolnych czy zawodowych, egocentryzm, zaburzenia osobowości, spadek libido, pauperyzacja możliwości intelektualnych, brak zainteresowania własnym zdrowiem i trudności finansowe [Zwolak 2018].

Jednym $\mathrm{z}$ zagrożeń związanych $\mathrm{z}$ funkcjonowaniem $\mathrm{w}$ cyberprzestrzeni jest tak zwany zespół uzależnienia od internetu (inne określenia to: siecioholizm, sieciozależność, cyberzależność, cybernałóg, internetoholizm, uzależnienie od internetu, uzależnienie komputerowe, infoholizm, infozależność) - w ramach tego zagrożenia wyraźnie widać, że z wymienionych wcześniej większość znajdzie swoje odzwierciedlenie właśnie tutaj. Badanie i analiza tych krzyżowych zagrożeń stanowi podstawę do całościowego zrozumienia problemu. Uzależnienie od komputera, gier komputerowych, a zwłaszcza internetu od początku 2018 roku wpisano do klasyfikacji ICD-11 jako jednostkę chorobową. Pod pojęciem ,zespołu uzależnienia od internetu” możemy rozumieć „zespół zależności polegających na wielogodzinnym korzystaniu z sieci Internet, które są dla pacjenta źródłem stresu oraz negatywnie wpływają na jego funkcjonowanie w sferze fizycznej, psychicznej, interpersonalnej, społecznej, rodzinnej i ekonomicznej" [Wallis 1997]. W literaturze można się spotkać z takimi terminami, jak: patologiczne używanie internetu, nadużywanie internetu, kompulsywne używanie internetu (w piśmiennictwie anglojęzycznym używane są następujące terminy: internet addiction disorder, internet addiction syndrome, internet abuse, compulsive internet use, pathological internet use). Uzależnienie, według WHO, występuje przy spełnieniu trzech warunków związanych z utratą kontroli nad czasem, nad znaczeniem przypisywanym grze oraz ignorowaniu negatywnych konsekwencji [Public Health Implications of Excessive Use of the Internet]. Z punktu widzenia dydaktyki komputerowe gry poprawiają zdolności wizualno-przestrzenne i koncentrację, co wspomaga procesy uczenia. Niestety, oddziałując też na tzw. układ nagrody, mogą powodować uzależnienie [Naukowcy analizują blaski... 2017]. Susan Flores poszła jeszcze dalej w odniesieniu do mediów społecznościowych, wprowadzając termin ,syndrom FAD”-Facebook addiction disorder [Flores 2017].

Dla Kimberly Young [1998] patologiczne używanie internetu to „zaburzenie kontroli nawyków niepowodujące intoksykacji, natomiast istotnie i wyraźnie pogarszające funkcjonowanie człowieka we wszystkich sferach jego życia". Autorka zaproponowała następującą metodę diagnostyczną przy spełnieniu 5 z 8 symptomów w ciągu ostatniego roku: 1) silne zaabsorbowanie internetem, przejawiające się ciągłym myśleniem o byciu online; 2) wzmagająca się potrzeba coraz dłuższego przebywania online, aby być z niej usatysfakcjonowanym; 3) powtarzające się, lecz nieudane próby kontroli własnego korzystania z internetu polegające na redukcji lub zaprzestaniu; 4) pojawianie się silnych negatywnych afektów w sytuacji ograniczania używania internetu, jak np. przygnębienie, irytacja itp.; 5) problemy z organizowaniem czasu przebywania online; 6) stres, problemy osobiste i społeczne wynikające z używania internetu; 
7) manipulacja w relacjach z otoczeniem, której celem jest ukrywanie informacji na temat własnego zaabsorbowania internetem; 8) regulacja emocjonalna przy pomocy aktywności internetowej, która przybiera formę ucieczki od problemów i uśmierzania negatywnych emocji.

Wśród podtypów zespołu uzależnienia od internetu Kimberly Young wymieniła między innymi erotomanię internetową (ang. cyber sexual addiction) ${ }^{9}$. Drugą formą zaburzeń jest socjomania internetowa (ang. cyber-relationship addiction) związana z potrzebą nawiązywania i utrzymywania kontaktów społecznych tylko przez sieć - powodująca ograniczenie, a nawet zanik kontaktów osobistych przy jednoczesnym upośledzeniu odbierania sygnałów komunikacji niewerbalnej, zubożenie języka aż do postępującego zamykania się we własnym świecie. Inną formą jest uzależnienie od sieci (ang. net compulsions) i uzależnienie od komputera. Uzależnienia te łączą w sobie wszystkie formy ZUI. Spektrum tych form należy poszerzyć o dalej idące problemy wynikające z tych zaburzeń. I tak, A. Hoalli i J. Parsons wprowadzili termin internet behavior dependece(IBD), czyli uzależnienie behawioralne. Autorzy stwierdzili, że patologiczne wykorzystywanie internetu może uszkodzić funkcje poznawcze, zaburzyć zachowanie i różne sfery zdrowia jednostki [Hoall, Parsons 2001], może nastąpić reorganizacja struktury potrzeb, doprowadzając jednostkę do chorób psychicznych, agresywnych zachowań skierowanych zarówno do siebie, jak i innych, bezdomności i atrofii struktur rodzinnych. W tym duchu Małgorzata Styśko-Kunkowska i Grażyna Wąsowicz, autorki raportu „Uzależnienia od e-czynności wśród młodzieży: diagnoza i determinanty”, wprowadzając pojęcie „e-czynności” jako jednostki aktywności powiązanej z nowymi technologiami zwróciły uwagę na różnorodne zagrożenia. $\mathrm{W}$ ich badaniach pojawiły się następujące niebezpieczeństwa:

1) wyobcowanie, które może być powiązane z wykluczeniem społecznym;

2) uzależnienie od gier, które może powodować brak lub utratę umiejętności nawiązywania relacji i współżycia w grupie;

3) zachowania agresywne słowne (wulgaryzmy) i fizyczne (niekontrolowane wybuchy agresji, pobicia), a nawet brak zdolności założenia własnej rodziny lub trudności z utrzymaniem relacji rodzinnych;

9 Przegląd wybranych zagrożeń zdrowotnych związanych z internetem: Ł.Wojtasik, Seksting wśród dzieci i młodzieży, „Dziecko Krzywdzone. Teoria, Badania, Praktyka” 2014, vol. 13, nr 2; E.R.Buhi, N. Klinkenberger, M. McFarlane, R. Kachur, E.M. Daley, J. Baldwin, H.D. Blunt, S. Hughes, C.W. Wheldon, C.A. Rietmeijer, Evaluating the Internet as a sexually transmitted disease risk environment for teens: findings from the communication, health and teens study, „Sex. Trans. Dis." 2013, vol. 40, nr 7, s. 528-533; H. Klein, Anonymous sex and HIV risk practices among men using the Internet specifically to find male partners for unprotected sex, „Public Health” 2012, vol. 126, nr 6, s. 471-481; A.A. Al-Tayyib, M.McFarlane, R. Kachur, C.A. Rietmeijer, Finding sex partners on the internet: what is the risk for sexually transmitted infection?, „Sex. Trans. Infect.” 2009, vol. 85, nr 3, s. 216-220. 
4) problemy szkolne i zawodowe związane z zaburzeniem uwagi, problemami z koncentracją oraz skupienie myśli tylko na tematyce związanej z daną e-czynnością.

Podejmowane $\mathrm{w}$ różnych państwach badania mające na celu zbadanie i opisanie skali zjawiska uzależnienia od internetu nie są jednak wystandaryzowane, tak aby wiarygodnie porównywać ich wyniki. W latach 2009-2010 w jedenastu państwach Europy przeprowadzono badania na grupie 12 tys. nastolatków. Analizy wskazały, że zaburzenia związane z korzystaniem z sieci dotyczą ok. 4,4\% z nich. Z kolei w Chinach, które jako pierwsze państwo już w 2008 roku zakwalifikowały uzależnienia internetowe jako zaburzenia psychiczne, stwierdzono, że uzależnionych może być więcej niż co dziesiąty internauta. $Z$ kolei badania przeprowadzone w 2012 r. przez CBOS dla Funduszu Rozwiązywania Problemów Hazardowych wykazały, że uzależnienie od sieci dotyczyło wówczas 100 tys. Polaków, a 750 tys. było na takie uzależnienie poważnie narażone [Stawikowski 2018].

Z kolei dla Macieja Tanasia młodzież korzystająca z nowych technologii informacyjnych może być narażona na zagrożenia dydaktyczne oraz psychiczne. Autor wyróżnił między innymi:

1) zaburzenia funkcji poznawczych prowadzące do niemożności kontynuowania nauki (zaburzenia percepcji, płynności uwagi, ograniczenie lub utrata zdolności logicznego myślenia, poczucie zagubienia, natrętne myśli, zachowania kompulsywne, zaburzenia pamięci, niemożność kontynuowania nauki jako konsekwencja wyżej wymienionych zaburzeń i objawów towarzyszących, związana np. z dyskomfortem psychicznym, pojawiającym się w wyniku drastycznych interwencji, tj. tzw. syndrom odstawienia, niekiedy o drastycznym przebiegu [Tanaś 1993];

2) ucieczka od świata realnego do sztucznego, wirtualnego: złudne poczucie siły i przynależności, często patologizującej rywalizacji (rekordy w grach) bez respektowania zasad etycznych; złudne poczucie wolności, bycia niezastąpionym, przymus bycia online, potrzeba autoprezentacji i poczucia obecności (własna strona www);

3) specyficzne postacie patologii społecznej: nieuzasadniona indywidualna lub zbiorowa agresja i autoagresja oraz frustracje; powielanie wzorców patologicznych i destrukcyjnych -agresja na ekranie ujawnia się w normach akceptowanych przez grupy rówieśnicze i społeczności lokalne (subkultury, lokalne nacjonalizmy, rejony podwyższonego ryzyka); dostęp do patologicznych grup o celach niejasnych, funkcjonujących na pograniczu lub poza prawem. Przystąpienie do nich jest równoznaczne z zaangażowaniem się lub byciem ofiarą (prostytucja, pornografia dziecięca, pedofilia, handel żywym towarem, organami itd.); dostęp do toksycznych grup kulturowych, parareligijnych, pseudoterapeutycznych, krypto lub jawnie satanistycznych, szerzących ideologię destrukcji, zła, agresji i nihilizmu; 
4) uzależnienia: syndrom internet addiction disorder - niejednorodne zjawisko uzależnienia od internetu, tj. wewnętrzny przymus bycia w sieci (wiąże zjawisko FOMO, czyli silny strach przed tym, że naszej uwadze umknie jakaś ważna informacja czy wydarzenie - ang. fear of missing out). Ulega mu 18\% użytkowników spędzających w internecie ponad 70 godzin tygodniowo; syndrom technohipnozy - popadanie w trans przez dzieci w trakcie emisji reklam lub gier komputerowych; syndrom ASC intensywne korzystanie z komputera może prowadzić do zmienionych stanów świadomości, podobnych fizjologicznie i psychologicznie do stanów intoksykacji farmakologicznej, alkoholowej czy narkotycznej. Syndrom ten ułatwia akceptowanie różnych nakazów i zakazów, także groźnych społecznie ideologii; uzależnienie od programów zawierających elementy psychomanipulacji, technik perswazyjnych, technik kontroli umysłu, technik bioneuromanipulacyjnych, działających na centralny układ nerwowy;

5) dysfunkcje neurologiczne: syndrom padaczki ekranowej, któremu w Japonii w roku 1997 uległo prawie 1000 osób; nerwice [Tanaś 1993].

Z kolei w pracy iMózg. Jak przetrwać technologiczna przemianę wspótczesnej umysłowości autorstwa G. Smallai i G. Vorgan [2011] zwrócono uwagę na zmiany strukturalne i funkcjonalne w neuronalnej budowie mózgu związane z długotrwałym korzystaniem z internetu. Zmiany te powodują określone konsekwencje i wpływają na procesy poznawcze człowieka.

\section{ZAGROŻENIA DLA ZDROWIA FIZYCZNEGO}

Obok problemów o charakterze psychicznym należy zwrócić uwagę na wiele konsekwencji dla zdrowia fizycznego. Niezdrowy tryb życia, brak aktywności, siedząca pozycja, stosowanie używek czy zaniedbywanie potrzeb fizjologicznych wpływają na ogólną kondycję człowieka.

Skutki fizjologiczno-fizyczne uzależniania od korzystania z technologii informacyjnych mogą być związane z ilością czasu, jaki użytkownik spędza w nienaturalnej dla człowieka pozycji ciała. Obsługa sprzętu stacjonarnego i mobilnego wymusza na użytkowniku przyjmowanie pozycji dostosowanej do posiadanego sprzętu. Wśród najczęstszych skutków uzależnienia od internetu (w wymiarze fizjologicznym) można wymienić: pogorszenie wzroku i słuchu, ból pleców i kręgosłupa (który może być jednym z objawów zmian zwyrodnieniowych), osłabienie układu odpornościowego (tym samym zwiększona podatność na infekcje), podrażnienia skóry (które są rezultatem nadmiernej podatności na cząsteczki kurzu i jonizowanie dodatnie urządzeń elektronicznych), bezsenność czy nadpobudliwość.

Dla części z tych dolegliwości opracowano termin RSI (ang. repetitive strain injury) - urazy na skutek chronicznego przeciążenia mięśni i ścięgien. Powstają one na skutek długotrwałego powtarzania czynności. Jest to dolegliwość 
rozpowszechniona wśród pracowników linii montażowych, osób piszących na klawiaturze, graczy używających myszy komputerowych, sekretarek i pracowników branży IT. Choroba ta jest związana z długotrwałym utrzymywaniem tej samej pozycji ciała oraz wykonywaniem powtarzających się czynności - obsługa komputera za pomocą myszy i klawiatury, praca narzędziami ręcznymi. W związku z zauważeniem tych zjawisk opracowano w ramach systemów operacyjnych Windows i Linux program Workrave, który ma za zadanie przypominanie o aktywności i proponuje określone zestawy ćwiczeń. Wycinkowe badania Marii Bartosińskiej, Jana Ejsmonta i Marii Tukalskiej-Parszuto przeprowadzone na grupie 477 osób pracujących na stanowiskach komputerowych skłoniły badaczy do stwierdzenia, że taka praca może stanowić zagrożenie nie tylko dla narządu wzroku, układu mięśniowo-kostnego, ale również jest obciążeniem psychicznym. Według danych Centralnego Instytutu Ochrony Pracy, na bóle w obrębie rąk, ramion, barku i szyi skarży się nawet $44 \%$ pracowników biurowych. Obok dolegliwości związanych z obciążeniem układu mięśniowo-szkieletowego problemem są zaburzenia funkcjonowania narządu wzroku. Według rozporządzenia MRPiPS, zalecane są takie sprzęty, jak: monitor regulowany w dwóch płaszczyznach $\left(5^{\circ} \mathrm{do}\right.$ przodu, $20^{\circ}$ do tyłu i po $60^{\circ}$ na boki wokół własnej osi), stół pozwalający na swobodne umieszczenie klawiatury $100 \mathrm{~mm}$ od jego przedniej krawędzi oraz krzesło, dzięki któremu zachowany będzie kąt minimum $90^{\circ}$ między ramieniem a przedramieniem. Dodatkowo wysokość siedziska powinna umożliwić obserwację monitora $\mathrm{w}$ zakresie $20^{\circ}-50^{\circ}$ poniżej linii oczu pracownika [Ergonomia w polskich biurach ... 2016]. Autorzy badania zwrócili również uwagę na różnego rodzaju promieniowania, w tym promieniowanie jonizujące (rentgenowskie), ultrafioletowe, podczerwone, radiowe oraz ultradźwięki, nie zauważając jednak ich niebezpiecznego oddziaływania [Bartosińska, Ejsmont, Tukalska-Parszuto 2001]. Najnowsze badania prowadzone przez A. M. Laverdurea, G. Ermakova, V. Bondarovskaja, I. Petrovskaja i innych, które dotyczyły szkodliwości promieniowania elektromagnetycznego o niskich częstotliwościach (do $50 \mathrm{~Hz}$ ) emitowanego przez ekrany monitorów komputerowych oraz telewizorów, jak również telefonów komórkowych, wskazują na powiązania z występowaniem chorób cywilizacyjnych. Autorzy stwierdzili, że pole elektromagnetyczne (SEM) powoduje obniżenie wydolności immunologicznej, co sprzyja rozwojowi chorób nowotworowych, a także powstawaniu alergii. Według badaczy pole elektromagnetyczne powoduje również częste infekcje, obniżenie płodności, zespół przewlekłego zmęczenia, problemy z zapamiętywaniem oraz wzrost zachowań nacechowanych agresją [Szymański]. Naukowcy z Zakładu Biofizyki Collegium Medicum Uniwersytetu Jagiellońskiego od listopada 2018 roku prowadzą nabór do badania związanego z analizą wpływu pola elektromagnetycznego (PEM) na zdrowie ${ }^{10}$. Według Światowej Organizacji Zdrowia sztuczne PEM, czyli to emitowane, jest

${ }^{10}$ Radni krakowscy od 2012 roku przygotowali już trzy petycje dotyczące promieniowania, według nich obwiązujący dotychczas sposób weryfikacji rzeczywistego narażenia mieszkańców na 
jednym z najbardziej powszechnych i najszybciej rozwijających się czynników zanieczyszczających środowisko. W 2011 roku sztuczne pola elektromagnetyczne zostały zaliczone przez WHO do Grupy 2B (możliwie rakotwórczych) [Broszura WHO 2009] ${ }^{11}$.

Interesującym badawczo problemem jest również wykorzystywanie informacji zamieszczanych $\mathrm{w}$ internecie do diagnozowania $\mathrm{z}$ poziomu domowego różnych dolegliwości. Dane wskazują, że w wielu państwach zastępowanie wizyty u lekarza korzystaniem z „Dr Google” stanowi duży problem [Doctor Google will see you now 2017] ${ }^{12}$. Uzupełnieniem tego zjawiska jest cyberchondria, czyli często nieuzasadnione, wzmożone zamartwianie się swoim stanem zdrowia, spowodowane poszukiwaniem $\mathrm{w}$ internecie informacji medycznych na temat objawów różnych chorób i dolegliwości. Jest to zaburzenie neurotyczne uważane za odmianę hipochondrii [Fergus 2013]. Innym niezwykle złożonym problemem jest Ruch pro-ana (professional-ana) - związany z promocją w sieci anoreksji. Jednym z haseł tego ruchu jest zdanie: quod me nutrit me destruit - „to, co mnie żywi, niszczy mnie” [Środek 2011]. Zgromadzenie Narodowe we Francji w 2008 roku przy olbrzymim sprzeciwie branży mody przyjęło ustawę nakładającą kary finansowe i kary więzienia za zachęcanie kobiet do ekstremalnej diety [Nie dla promowania anoreksji 2008]. Inne państwa również planują takie działania.

Kolejnym problemem są cybersamobójstwa (w języku angielskim net suicides, cybersuicide) i cała subkultura związana z licznymi stronami internetowymi i forami, na których młodzi ludzie zachęcają się do popełniania samobójstw, zawiązują pakty, w których zobowiązują się do wspólnego popełnienia samobójstwa i opisują metody, jakimi można je popełnić [480 stron internetowych dotyczących samobójstw, z czego 45 zachęcało do samobójstwa (pro-suicide) i na 43 opisywane są metody samobójstw] [Drzewiecki 2011]. Najgłośniejsze i najliczniejsze wypadki tego typu zanotowano w Japonii, gdzie rocznie dochodzi do około 60 takich przypadków [Birba i in. 2009].

Przeprowadzono również pierwsze badanie, które wskazuje na tak zwaną „cyfryzację sypialni”, którą należy rozumieć jako „niezdolność do odstawienia smartfonów, zamknięcia laptopów czy wyłączenia telewizorów przed snem". Emitowane przez sprzęt światło hamuje produkcję melatoniny, a to utrudnia zasypianie. Na łamach pisma „Ophthalmic \& Physiological Optics” opisano eksperyment, w którym naukowcy sprawdzili wpływ działania ekranów na poziom melatoniny i sen w grupie osób od 17 do 42 lat. Autorzy zwrócili uwagę na następujące zagadnienia: zaburzenia funkcji poznawczych, ogólne rozdrażnienie,

PEM (pole elektromagnetyczne) jest niewystarczający. Również NIK w 2018 roku zajął się sprawą tak zwanego elektrosmogu.

${ }^{11}$ Więcej na ten temat: [Kasprzyk, Butlewski 2013:19-31].

12 Serwis Statista na podstawie danych Eurostatu pokazal, jak w 12 państwach UE w okresie 2006-2016 użytkownicy posługiwali się internetem do diagnozowania, najczęściej robili to obywatele Luksemburga (71\%), Danii (65\%), Niemiec (63\%), Polacy (40\%), Włosi (31\%). 
spadek sił witalnych, nadmierne pobudzenie, cukrzyca i nadwaga, depresja i niska samoocena [Kulik 2018].

Przedstawione zjawiska nie wyczerpują katalogu możliwych konsekwencji zdrowotnych dla społeczeństw i jednostek, tym bardziej że rozwój technologii informatyczno- komunikacyjnych znacznie przyspiesza, nie dając czasu na utrwalenie i refleksję nad istotą zmian.

\section{KONKLUZJE}

Bezpieczeństwo zdrowotne i zagrożenia bezpieczeństwa zdrowotnego będą stanowić wyzwanie dla badaczy, którzy analizując problemy z pogranicza medycyny, psychologii, polityki społecznej, edukacji, socjologii, prawa, informatyki i wielu innych, będą poszukiwać rozwiązań pozwalających pogodzić nieuchronny i dynamiczny rozwój technologii informatyczno-komunikacyjnych z ograniczeniami fizyczno-psychologicznymi jednostek. Rozwój technologii informacyjnych to proces wymagający stałego monitorowania zmian i analizy zachodzących w związku z tym przeobrażeń. Ważnym elementem powinno być przemodelowanie systemu edukacji na każdym szczeblu, aby od najmłodszych lat kształcić użytkowników, którzy będą świadomi zarówno korzyści, jak i zagrożeń płynących z nowoczesnych technologii informacyjnych, a także tempa zmian, które będzie wymagało nieustannego podnoszenia kwalifikacji w tej dziedzinie. Jednocześnie rozwój aparatury i zaplecza badawczego oraz długofalowe badania pozwolą trafnie prognozować wpływ tak pozytywny, jak i negatywny na użytkowników. Nie można oczywiście wskazać, że technologie informacyjno-komunikacyjne generują jedynie zagrożenia. Ich znaczenie i pozytywne oddziaływanie na wiele sfer życia społecznego jest znaczące, niemniej jednak należy stale mieć na uwadze, że „cyfrowe zanurzenie” i zaproponowane przez Wiesława Babika określenie antropoinfosfera (otoczenie informacyjne człowieka) [Babik 2002] to stale poszerzająca się przestrzeń dostarczająca zarówno pozytywnych, jak i negatywnych w konsekwencjach rozwiązań.

Title: Threats to Health Security related to Information and Communication Technologies

Summary: The article attempts to capture basic elements related to threats to social security in cyberspace. Attention was paid to various categories of intersecting themes covering health risks. The subject of health security in information technology is a difficult research area because the speed and deepening penetration through virtual reality causes overlapping of various elements. Cyberspace and cyber security are challenge for authors dealing with this issue as well as for practitioners from various fields facing the challenge of predicting and preventing potentially dangerous phenomena.

Keywords: Internet, threat security, information technology 


\section{BIBLIOGRAFIA}

1. 2018 Q2 Global Digital Statshot, (2015), We are Social, Hootsuite, https://wearesocial.com [dostęp: 2.05.2018].

2. Babik W. (2002), Eko-logia informacji-wyzwanie XXI wieku, „Praktyka i Teoria Informacji Naukowej i Technicznej”, nr 1(37).

3. Bartosińska M., Ejsmont J., Tukalska-Parszuto M. (2001), Chorobowość pracowników zatrudnionych na stanowiskach pracy wyposażonych w komputery, „Medycyna Pracy”, nr 52, 3.

4. Bezpieczeństwo prawne. Nowy poziom bezpieczeństwa narodowego, (2009), [w:] Bezpieczeństwo wewnętrzne Rzeczpospolitej Polskiej na tle innych państw Unii Europejskiej. Stan obecny oraz perspektywy zmian, Wyższa Szkoła Gospodarki Euroregionalnej, Józefów.

5. Birba R.L, Birba R.L, Lapperton M., Jarvis J., Ragoonath A., Uppalapati K., Maharajh H.D. (2009), Cybersuicide and the adolescent population: Challenges of the future?, https://www. researchgate.net/publication/26762475_Cybersuicide_and_the_adolescent_population_Challenges_of_the_future, International journal of adolescent medicine and health 21(2): $151-9$, April 2009 [dostęp: 20.05.2018].

6. Borowska T. (2009), The Internet addiction versus aggressive behaviour among the youth, "The New Educational Review", nr 19.

7. Broszura WHO, (2009), Wpływ pola elektromagnetycznego na zdrowie człowieka. Płaszczyzny dialogu, Warszawa, https://www.piit.org.pl/_data/assets/pdf_file/0019/9433/broszura_WHO_ krawczyk_pem_plaszczyzny_dialogu.pdf [dostęp: 3.01.2019].

8. Buzan B., Wæver O., de Wilde J. (1998), Security. A New Framework for Analysis, London.

9. Chen W., Wellman B. (2004), The global digital divide within and between countries, "IT \& Society", nr1 (7), s. 39-45.

10. Cudo A., Stróżak P., Kopiś N. (2016), Raport z projektu badawczego ,,Specyfika funkcjonowania poznawczego osób uzależnionych od Internetu oraz osób uzależnionych od gier komputerowych", Lublin.

11. DiMaggio P., Hargittai E. (2001), From the 'Digital Divide' to 'Digital Inequality': Studying Internet Use as Penetration Increases, "Working Paper", No. 15.

12. Doctor Google will see you now, https://www.telegraph.co.uk/health-fitness/mind/dr-google-will-see-now-day-life-cyberchondriac/ [dostęp: 17.02.2019].

13. Drzewiecki P. (2011), Samobójstwa nastolatków w Internecie w perspektywie pedagogiki mediów, „Kultura, Media, Teologia”, nr 5.

14. Dworecki S. (2002), Zagrożenia bezpieczeństwa państwa, AON, Warszawa.

15. Encyklopedia zarzadzania, 2018, red. M. Rewizorski, K. Bieniek, Warszawa.

16. Ergonomia w polskich biurach leży $i$ woła o pomoc, 2016, http://www.rynekzdrowia.pl/Po-godzinach/Ergonomia-w-polskich-biurach-lezy-i-wola-o-pomoc, 161244,10.html

17. Fergus T.A. (2013), Cyberchondria and Intolerance of Uncertainty: Examining When Individuals Experience Health Anxiety in Response to Internet Searches for Medical Information, „Cyber psychology, Behavior, and Social Networking”, vol. 16, No. 10, https://www.liebertpub. com/doi/10.1089/cyber.2012.0671[dostęp: 20.05.2018].

18. Flores S.E. (2017), Sfejsowani. Jak media społecznościowe wpływaja na nasze życie, emocje i relacje z innymi, tłum. K. Mojkowska, Warszawa.

19. Foulger D. (2001), Seven bridges over the global digital divide, IAMCR \& ICA Symposium on Digital Divide. 
20. Furmanek W. (2014), Zagrożenia wynikające z rozwoju technologii informacyjnych, „Dydaktyka Informatyki", nr 9.

21. Groth J. (2010), Cyberstalking - perspektywa psychologiczna, „Forum Oświatowe”, nr 2/43.

22. Hoall A., Parsons J. (2001), Internet Addiction: Collage Student Case Study Using Best Practices in Cognitive, Therapy, „Journal of Mental Health Counseling”, nr 23.

23. Internet access of households, (2017), https://ec.europa.eu/eurostat/statistics-explained/index. php?title=Digital_economy_and_society_statistics_-_households_and_individuals/pl\#Korzystanie_z_internetu

24. Internet usage statistics. The Internet Big Picture, (2018), World Internet Users and 2018 Population Stats, https://www.internetworldstats.com/stats.htm [dostęp: 26.04.2018].

25. Jędrzejko M. (2013), Cyfrowi tubylcy: socjopedagogiczne aspekty nowych technologii cyfrowych, Warszawa.

26. Kasprzyk R., Butlewski M. (2013), Pole elektromagnetyczne jako czynnik szkodliwy w przemyśle elektromagnetycznym, „Zeszyty Naukowe Politechniki Poznańskiej”, nr 59, „Organizacja i Zarządzanie", s. 19-31.

27. Konieczniak M. (2011), Poszukiwanie tożsamości w cyberprzestrzeni. Implikacje pedagogiczne, „Edukacja i Dialog”, nr 5/6.

28. Kulik W. (2018), Szybki internet szkodzi zdrowiu, zaburzenia snu, http://www.benchmark.pl/ aktualnosci/szybki-internet-szkodzi-zdrowiu-zaburzenia-snu.html

29. Leavitt H.J., Whisler T.L. (1958), Management in the 1980s, "Harvard Business Review", https://hbr.org/1958/11/management-in-the-1980s [dostęp: 3.01.2019].

30. Leszczyński M. (2011), Bezpieczeństwo społeczne Polaków wobec wyzwań XXI wieku, Warszawa.

31. Lévy P. (2018), Drugi potop, http://www.tezeusz.pl/cms/tz/index.php?id=287 [dostęp: 6.05.2018].

32. Loranty K. (2012), Percepcja zagrożeń, „Zeszyty Naukowe AON”, nr 3 (88), s. 10-18.

33. Majer P. (2012), W poszukiwaniu uniwersalnej definicji bezpieczeństwa wewnętrznego, „Przegląd Bezpieczeństwa Wewnętrznego", nr 7/12.

34. National Cancer Research Centre, Tokyo, Japan 27-29 August 2014, http://apps.who.int/ iris/bitstream/handle/10665/184264/9789241509367_eng.pdf;jsessionid=BCA387AB1E3B406E91F8046F9FBCEEF9?sequence=1 [dostęp: 21.05.2018].

35. Naukowcy analizuja blaski i cienie gier komputerowych, http://www.rynekzdrowia.pl/Badania-i-rozwoj/Naukowcy-analizuja-blaski-i-cienie-gier-komputerowych,174063,11.html [dostęp: 3.01.2019].

36. Nie dla promowania anoreksji, (2008), http://wiadomosci.gazeta.pl/wiadomosci/1, 114881,5123540.html [dostęp: 20.05.2018].

37. Nowina-Konopko M. (2006), Istota i rozwój społeczeństwa informacyjnego, [w:] Społeczeństwo informacyjne. Istota, rozwój, wyzwania, Warszawa.

38. Pietraś M. (1996), Bezpieczeństwo ekologiczne w Europie, Lublin.

39. Polski Internet w marcu 2018, (2018), Badanie Gemius PBI z 10 marca 2018, http://pbi.org.pl/ badanie-gemius-pbi/polski-internet-marcu-2018/ [dostęp: 20.05.2018].

40. Prezentacja treści seksualnych przez młodzież poprzez wideoczaty. Badania, dyżur.net, NASK, (2013) Research.nk [dostęp: 13.06.2018].

41. Public Health Implications of Excessive Use of the Internet, Computers, Smartphones and Similar Electronic Devices, (2014), Meeting report Main Meeting Hall, Foundation for Promotion of Cancer Research. 
42. Pyżalski J. (2011), Agresja elektroniczna wśród dzieci i młodzieży, Gdańsk.

43. Pyżalski J., Klichowski M., Przybyła M. (2014), Szanse i zagrożenia w obszarze wykorzystania technologii informacyjno-komunikacyjnych (TIK), ze szczególnym uwzględnieniem aplikacji mobilnych (TIK-mobApp) przez dzieci w wieku 3-6 lat, Poznań.

44. Raport Newspoint: Pokolenia w Polsce i potrzeba monitorowania ich rosnącej aktywności, (2018), https://blog.newspoint.pl/index.php/2018/03/21/raport-newspoint-pokolenia-w-polsce-i-potrzeba-monitorowania-ich-rosnacej-aktywnosci/ [dostęp: 12.06.2018].

45. Skrabacz A. (2012), Bezpieczeństwo społeczne. Podstawy teoretyczne i praktyczne, Warszawa, s. 38.

46. Small G., Vorgan G. (2011), iMózg. Jak przetrwać technologiczna przemianę współczesnej umystowości, Wydawnictwo Vesper, Poznań.

47. Środek I. (2011), Motyle w sieci. Krótka charakterystyka ruchu pro-ana, „Current Problems of Psychiatry", nr 12 (3), http://www.psychologia.net.pl/artykul.php?level=461[dostęp: 20.05.2018].

48. Środek I. (2011), Motyle w sieci. Krótka charakterystyka ruchu pro-ana, „Current Problems of Psychiatry”, nr 12 (3), s. 322-329, http://www.psychologia.net.pl/artykul.php?level=461 [dostęp: 20.05.2018].

49. Stawikowski Ł. (2018), Uzależnienie od internetu - objawy i leczenie siecioholizmu, https://www.medicover.pl/o-zdrowiu/uzaleznienie-od-internetu-objawy-i-leczenie-siecioholizmu,6339,n,192.

50. Szpunar M. (2004), Społeczności wirtualne jako nowy typ społeczności-eksplikacja socjologiczna, „Studia Socjologiczne”, nr 2 (173).

51. Tanaś M. (1993), Medyczne skutki uboczne kształcenia wspomaganego komputerowo, „Toruńskie Studia Dydaktyczne", nr 3.

52. United Nations Development Program Human Development Report 1994, (1994), New York.

53. Uzależnienia od e-czynności wśród młodzieży: diagnoza i determinanty. Raport, (2014), oprac. M. Styśko-Kunkowska, G. Wąsowicz, www.kbpn.gov.pl/portal?id=15\&res_id=5064290

54. Wallis D. (1997), Just Click No, „The New Yorker”, https://www.newyorker.com/magazine/1997/01/13/just-click-no [dostęp: 21.05.2018].

55. Wąsiński A. (2003), Kultura informatyczna jako nowy wymiar uczestnictwa $w$ życiu społeczno--kulturowym współczesnego człowieka, „Nauczyciel i Szkoła”, nr 1-2 (18-19), s. 113-119.

56. Witaszek Z., Bezpieczeństwo społeczne, [w:] Wybrane problemy bezpieczeństwa. Dziedziny bezpieczeństwa, red. A. Urbanek, Słupsk 2013, s. 194-195.

57. Wojtasik Ł. (2009), Przemoc rówieśnicza z użyciem mediów elektronicznych - wprowadzenie do problematyki, „Dziecko Krzywdzone”, nr 1/26.

58. Wojtasik Ł. (2014), Seksting wśród dzieci i młodzieży, „Dziecko Krzywdzone. Teoria. Badania. Praktyka", nr 13 (2).

59. Yapp R. (2012), Three-quarters of British children aged 10 own a mobile phone - twice as many as overseas, http://www.dailymail.co.uk/news/ article-2198450/Three-quarters-Britishchildren-aged-10-mobile-phone--twice-overseas.html\#ixzz358DpOqIL [dostęp: 20.05.2018].

60. Zięba R. (1999), Instytucjonalizacja bezpieczeństwa europejskiego, Warszawa.

61. Zięba R. (2012), O tożsamości nauk o bezpieczeństwie, „Zeszyty Naukowe AON”, nr 1 (86).

62. Zwolak E., Uzależnienie od Internetu (siecioholizm) - objawy, rodzaje i skutki! Sprawdź, jak leczyć uzależnienie od komputera!, https://echodnia.eu/swietokrzyskie/uzaleznienie-od-internetu-siecioholizm-objawy-rodzaje-i-skutki-sprawdz-jak-leczyc-uzaleznienie-od-komputera/ ar/13645143 